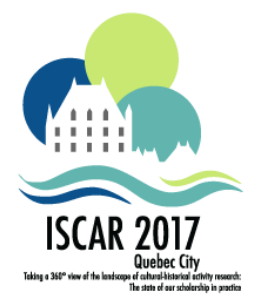

\title{
Old Age as a Cultural and Historical Phenomenon and its Transformation in Modern Times
}

\author{
Marina V. Ermolaeva \\ Moscow Psychological-Social University \\ Moscow, Russia
}

\begin{abstract}
Old age, like any other age, is a cultural and historical phenomenon. In the culture and mass consciousness the viewpoint about elderly and old age as the period of involution is still prevalent. At the same time, there has been a change in attitude toward this age. Many authors emphasize the perspective of using the potential of older people in society, the value of continued employment to maintain social and intellectual activity in old age. This is possible only if a person realized the need for continuous creation of themselves and their living conditions.

Currently, the ending of the life of modern people has moved from 60 to 80 years. Thus, after retirement, the person has a chance to live around 20 years of valuable productive life. This means that contemporary people's life path has a completely new period, which did not exist before. At that time, when the previous life attitudes were realized, the person opens up new possibilities of self-development in other areas. People on their life become able to realize the potential of self-development and to resist the pressure of adverse cultural forces. At any age the opinion about people's abilities has a significant impact on the life efficiency and quality. Conscious and productive change in the trajectory of person's own life path not only questioned the idea of the inevitability of negative changes in the quality of life in old age, but also "removes" the problems of this age, as constant depression, deficiency and weakness.
\end{abstract}

Keywords : Elderly and old age; Modern times; Life efficiency; Life quality; Depression, deficiency and weakness. 
Old age, like any other age, is a cultural-historical phenomenon. In developmental psychology, the old age is considered in the context describing the whole path of a person's life. Any handbook on developmental psychology contains a description of old age. However, the analysis of these representations is puzzling: Are authors writing on the same age? Their understanding of goals, content and developmental opportunities in old age are too different. On the one hand, authors notice the adoption of ageing which opens the possibility to review the existential being (not an active adaptation to the sociocultural reality, but the search of person's own place in the universe, making a sense of completion of life, the feeling of fatigue from her and the exit out of the sphere of obligation) as the most important tasks of this age (Sapogova, 2011). In this approach, which is supported by some authors, the real social life is aside from the elderly people, and old age is considering as the period of summing up life. Many authors associate the old age with withdrawal of elder people from active life and deepening into their inner world, in their way of passed life.

On the other hand, there are ideas about old age which claiming the possibility of using the potential of older people in society, the value of continued employment to maintain social and intellectual activity in old age, the need for continuing of education throughout life path (Ermolaeva, 2011). The impression is that the term "old age" means different periods of life for different authors. Those psychologists, who write on aging as the involution, they view it from the outside as a "foreign" problem distanced from it. As a result, the old age is represented as the final outcome of not entirely successful scenario of life which has no alternative. But is it true? To answer this question, it is necessary to define time frames of old age.

In different fields of science different criteria are using. In gerontology, retirement is considered as the boundary of old age. Currently, this criterion also is not sufficiently compelling because for many people, retirement is a basis for a change of activity that, not only important for maintaining intellectual and personal potential, but also for their development (Ermolaeva, 2011). In general, attempts to give a clear definition of old age and even to designate its borders are not successful because the aging process is for everybody. In other words, there is no general, identical for all people, final stage of life.

The contours of life path are marked in youth, when the person is able to take consciously the estimated position in relation to his life and is able to dispose of it, to organize the life consciously, making efforts, when all life appears for him as unfolded in time system of voluntary choices, when people realize themselves as the creators of their own life's world. Whatever reflective or responsible is the choice of life which person will carry out, this choice will depend on the success of her/his maturing and aging. In each age a person enters into a new system of socio-psychological relations in which he has to create his own unique life-world and to learn new ways of living, thus confirming (or refuting) your choice (Antsyferova, 2006).

We refer to the idea of S. L. Rubinstein about the two ways of existence (Rubinshtein, 2012) to understand the choices of life. The first way is a life not beyond direct relations in which person lives, where every attitude is the attitude to individual phenomena, but 
not to life in general. In this case the person is not able to rise above his existence to his reflection. The second way, according to S. L. Rubinstein, is associated with the person's mental exist beyond the ties that determine his existence. This second way is associated with the development of reflection, with the advent of value-semantic definition of life, with a conscious choice of life, sense of life, because it implies the need for understanding human's relationship to the life and the need to find inner resources for change (Rubinshtein, 2012). In psychology, the first way of life is called adaptive, the second called active, since the latter is accompanied by the experience of the intentional direction of his own life.

In our opinion, these two ways of life determine fundamentally different, not reducible to each other trajectories of human life, and respectively, the different content of the late stages of life. Thus, in the case of adaptive way of life the process of aging is, above all, a natural biological process of involution, not held back by self-development and responsibility for building their own lives. In the case of adaptive way of life, the involutional changes associated with aging "run" like the program of biological development of the body, including growth and ability to reproduce. Old age creeps up gradually, but steadily, the person noticing it, begins to fear old age and everything connected with it.

A different picture emerges with the active way of life. This way is characterized by purposeful and conscious self-development, where the change itself becomes a special form of transformation activity. In this active, spiritual trajectory of the life of a person's path is consciously making an effort to make sense of her/his vital-creative strength potential, to realize their intentions, aspirations for future development, and most importantly, in actions, in transforming, creative activity. Adult development is not predetermined, it is given as a possibility, and a person who has reached adulthood, may not have all the characteristics of a mature personality. This way of life really is the way of cultural development in old age. Stagnation in development can occur at any point of the life path of an adult, followed by involution, which represents the aging. In this regard, can hardly be considered scientifically valid merging into one concept of "old age" elder people, characterized by different ways of life and different trajectories of life path. Indeed, chronological coevals in this period seem to us as representatives not only of different ages but also different historical periods, which are characterized by a different attitude to old age.

Development trajectory which defined by a way of life, so different that the concept of "old age" in one case means "the undergoing" suffering of total dependence on the conditions of existence and their own condition' deteriorating, and in another case, the continuation of progressive development of personality, productivity, and spirituality of life, which realized in actions. In the second case, when people realized the need for continuous creation and creative transformation of themselves and their living conditions, is it possible to say about old age as an inevitable result of the existence? The person on life path creates a space of his own life, its own unique life-world, becomes the master of his destiny, able to withstand the pressure of adverse social and cultural forces, and learns to protect your world and your identity, because these gains do not come for free. 
Currently, the ending of the life of modern people has moved from 60 to 80 years. Thus, after retirement, the person has a chance to live around 20 years of valuable productive life. This means that contemporary people's life path has a completely new period, which did not exist before. At that time, when the previous life attitudes were realized, the person opens up new possibilities of self-development in other areas.

Finally, a rather sharp age crisis (life fracture) occurs before retirement. There is a perception that the severity of the crisis associated with the "depletion of active form of life" (Slobodchikov \& Isaev, 2000) when things lose relevance for a middle-aged person, become obsolete, students are ahead of him, the children grow up and not need her/his experience and support, and she/he has not kept pace for modern technologies. And, apparently, it's time to accept the fact of the inevitability of retreat in the life to come to terms with aging in body and in soul and to look to the past. However, the latest age crisis (like all previous) is a chance to update targets, semantic orientations; a chance for self-development. It is possible to agree with E. Erickson that the contents of the final stage of life depends on successful completion of all previous stages. Once embarked on the path of conscious self-development, creativity, people will find the opportunity to continue it on the final stage of life path. Even then, when thinking about the possibility of purposeful life changes for the better after retirement seem sudden, not having prerequisites, there is no doubt in their deep rootedness in the already accomplished inner work of self-creation, accountability for past actions. In other words, the person feels the need and the will to update, feeling a willingness to change, the person enters into a new relationship to the world and to ourselves. The person would no longer be treated to the difficulties of living conditions with humility and fear. Period starting after recent age crisis is associated with the search for new grounds of meaningful existence, for a new phase of self-determination. The trajectory of the life path is the most important thing (or rather a series of actions), which determines the progressive development of the personality at this stage. If a person finds that he makes her/his personal contribution, she/he argues the self-esteem and confident attitude to life. It is known that at any age, opinion about their abilities has a significant impact on the efficiency and quality of human life. If people in the crisis of elder age are not felt ready to update life goals, they lose their professional future, filled with ideas, problems, plans, if they excluded from the system of interpersonal peer-relations that negate age-related segregation.

Analysis of the patterns of changes in life in moments of crisis have shown that a person selecting for an active way of living and experiencing in this way all his allotted challenges, disappointments and rebirth, one gets the chance of progressive development throughout life, and with it a deep satisfaction with their lives. This experience is determined by the conviction of people that their way is the realization of the own life plan, which became meaningful and, therefore, a good choice of possible life alternatives, the fruit of his consistent effort. It should not be assumed that a hasty, wrong choice in his youth negates the possibility of progressive development : any age crisis (if it is experienced reflective and heavily) has a chance to be completed the entry on a path of meaningful existence. The range of individual possibilities is fundamentally indeterminate, and the development is 
not restricted to any specific periods of human existence, it is carried out throughout life (Antsyferova, 2006).

This period of life (often called "late maturity") ends by the moment when the biological capacity is depleted and this process affects the ability of a person to action - to act. Can we call this period the "decrepitude" full disability? Yes, if an elderly person is concentrated in the struggle for life in its vital needs, on the sensations of body and inside of body. But choice the path of meaningful existence determines the possibility of the release of "beyond" at the very late stage (beyond concentration on itself, pain, frailty, the proximity of death) to another person, to the values of creativity, emotions, relations (Frankl, 2012), to trans-vital sense.

At any age, people's opinion about their abilities has a significant impact on the efficiency and quality of human life. Conscious and productive change in the trajectory of person's own way of life not only casts doubt on the idea of the inevitability of negative changes in the quality of life in old age, but also "removes" such problems of this age as the constant depression, deficiency and impotence. Selecting for an active way of life, people consistently move to the height of maturity and late maturity. Old age in the traditional sense has no place on this life path, there is no place for the fear of old age. However, the progressive development of life is given with great effort of 'overstep through own self', with the refusal of opportunities seem attractive, but which are not authentic, not relevant for life design. At the final stage of life, summing up its results, one person will take your way of life as the only needs, and does not need to be replaced, as the author, truly, "your", and the other will feel cheated by life. This probably shows the difference in the outcomes of life as the end of a fading (old age) or as a meaningful completion of all begun affairs, fruitful realization of life goals and the transfer of development to future generations.

\section{References}

Antsyferova, L. I. (2006). Razvitie lichnosti i problemy gerontopsikhologii [Personality development and the problems of gerontopsychology]. Moscow: Institute of psychology RAN Pabl.

Ermolaeva, M. V. (2011). Psikhologo-pedagogicheskoe soprovozhdenie pozhilogo cheloveka [psychological and pedagogical support of elderly person]. Moscow, Russia: NOU VPO Moskovskii psikhologo-sotsial'nyi universitet [The Moscow Psychological and Social University].

Frankl, V. (2012). Stradaniya ot bessmyslennoi zhizni [Suffering from a meaningless life]. Novosibirsk: Sib. Universitet Publ. (in Russ).

Rubinshtein, S. L. (2012). Chelovek i mir [Man and the world]. Moscow: Pedagogika.

Sapogova, E. E. (2011). Ekzistentsial'no-psikhologicheskii analiz starosti [Existentialpsychological analysis of old age]. Kul'turno-istoricheskaya psikhologiya [Cultural-historic psychology].(3), 75-81.

Slobodchikov, V. I., \& Isaev, E. I. (2000). Psikhologiya razvitiya cheloveka [psychology of human development]. Moscow: Shkol'naya Pressa. 